Article

\title{
Oleic Acid Protects Against Insulin Resistance by Regulating the Genes Related to the PI3K Signaling Pathway
}

\author{
Carlos López-Gómez ${ }^{1,+} \oplus$, Concepción Santiago-Fernández ${ }^{1,+} \oplus$, Sara García-Serrano ${ }^{2,3} \mathbb{1}$, \\ Eva García-Escobar ${ }^{2,3}{ }^{\circledR}$, Carolina Gutiérrez-Repiso ${ }^{4}$, Cristina Rodríguez-Díaz ${ }^{1}$ (D), \\ Ailec Ho-Plágaro ${ }^{1}$, Flores Martín-Reyes ${ }^{1}$, Lourdes Garrido-Sánchez ${ }^{4,5}$, Sergio Valdés ${ }^{2,3}{ }^{(D)}$, \\ Alberto Rodríguez-Cañete ${ }^{6}$, Francisca Rodríguez-Pacheco ${ }^{1,3, *}$ and Eduardo García-Fuentes ${ }^{1, * \text { (D) }}$ \\ 1 Unidad de Gestión Clínica de Aparato Digestivo, Hospital Universitario Virgen de la Victoria/Instituto de \\ Investigación Biomédica de Málaga-IBIMA, 29010 Málaga, Spain; carlos.lopez@ibima.eu (C.L.-G.); \\ conchisantiagofernandez@gmail.com (C.S.-F.); cris.rdrz@gmail.com (C.R.-D.); \\ ailec_hp@hotmail.com (A.H.-P.); floresmarey@hotmail.com (F.M.-R.) \\ 2 Unidad de Gestión Clínica de Endocrinología y Nutrición, Hospital Regional Universitario de \\ Málaga/Instituto de Investigación Biomédica de Málaga-IBIMA, 29010 Málaga, Spain; \\ garciasara79@hotmail.com (S.G.-S.); eyring@gmail.com (E.G.-E.); sergio.valdes@hotmail.es (S.V.) \\ 3 CIBER de Diabetes y Enfermedades Metabólicas Asociadas-CIBERDEM, 29010 Málaga, Spain \\ 4 Unidad de Gestión Clínica de Endocrinología y Nutrición, Hospital Universitario Virgen de la \\ Victoria/Instituto de Investigación Biomédica de Málaga-IBIMA, 29010 Málaga, Spain; \\ carogure@hotmail.com (C.G.-R.); lourgarrido@gmail.com (L.G.-S.) \\ 5 CIBER Fisiopatología de la Obesidad y Nutrición-CIBEROBN, 29010 Málaga, Spain \\ 6 Unidad de Gestión Clínica de Cirugía General, Digestiva y Trasplantes, Hospital Regional Universitario \\ de Málaga, 29010 Málaga, Spain; arodriguezcane@hotmail.com \\ * Correspondence: paqui.endocrino@gmail.com (F.R.-P.); edugf1@gmail.com (E.G.-F.) \\ + These authors contributed equally to this work.
}

Received: 17 June 2020; Accepted: 10 August 2020; Published: 12 August 2020

\begin{abstract}
Background: The effects of different types of fatty acids on the gene expression of key players in the IRS1/PI3K signaling pathway have been poorly studied. Material and Methods: We analyzed IRS1, p $85 \alpha$, and p110 $\beta$ mRNA expression and the fatty acid composition of phospholipids in visceral adipose tissue from patients with morbid obesity and from non-obese patients. Moreover, we analyzed the expression of those genes in visceral adipocytes incubated with oleic, linoleic, palmitic and dosahexaenoic acids. Results: We found a reduced IRS1 expression in patients with morbid obesity, independent of insulin resistance, and a reduced $\mathrm{p} 110 \beta$ expression in those with lower insulin resistance. A positive correlation was found between $\mathrm{p} 85 \alpha$ and stearic acid, and between IRS1 and p110 $\beta$ with palmitic and dosahexaenoic acid. In contrast, a negative correlation was found between p85 $\alpha$ and oleic acid, and between IRS1 and p110 $\beta$ with linoleic, arachidonic and adrenic acid. Incubation with palmitic acid decreased IRS1 expression. p85 $\alpha$ was down-regulated after incubation with oleic and dosahexaenoic acid and up-regulated with palmitic acid. p110 $\beta$ expression was increased and decreased after incubation with oleic and palmitic acid, respectively. The ratio $\mathrm{p} 85 \alpha / \mathrm{p} 110 \beta$ was decreased by oleic and dosahexaenoic acid and increased by palmitic acid. Conclusions: Our in vitro results suggest a detrimental role of palmitic acid on the expression of gene related to insulin signaling pathway, with oleic acid being the one with the higher and more beneficial effects. DHA had a slight beneficial effect. Fatty acid-induced regulation of genes related to the IRS1/PI3K pathway may be a novel mechanism by which fatty acids regulate insulin sensitivity in visceral adipocytes.
\end{abstract}


Keywords: morbid obesity; insulin resistance; IRS1; p85 $\alpha$; p110 $\beta$; palmitic acid; oleic acid; docosahexaenoic acid; linoleic acid; visceral adipose tissue

\section{Introduction}

Insulin resistance (IR) is a common complication in obesity and leads to the development of the metabolic syndrome and Type 2 Diabetes Mellitus (T2DM). IR is characterized by an abnormally reduced cell response to insulin signaling in target cells, such as adipocytes, hepatocytes, and skeletal muscle. After the binding of insulin with its receptor [1], docking proteins insulin receptor substrate (IRS) 1, 2, 3, and 4, as well as several Shc proteins, are mobilized to the intracellular domain of the insulin receptor. IRS1 and IRS2 are strongly expressed in insulin-sensitive tissues [2] and are responsible for many of the metabolic effects of insulin through the activation of phosphatidylinositol 3 kinase (PI3K). Mice with a targeted disruption of the IRS1 gene show either insulin resistance [3] or T2DM [4].

PI3K exists as a heterodimer composed of a catalytic subunit associated with a regulatory subunit. Among those subunits, $\mathrm{p} 85 \alpha$ (regulatory) and p110 $\beta$ (catalytic) are some of the most studied ones. There are two widely distributed isoforms of the catalytic subunit, $\mathrm{p} 110 \alpha$ and $\mathrm{p} 110 \beta$, the latter being highly insulin-sensitive [5]. In fact, two mechanisms involving this pathway have emerged as being mainly responsible for the development of IR: Serine phosphorylation of IRS1 [6,7], and increased expression of $\mathrm{p} 85 \alpha$ and alteration of the stoichiometry with $\mathrm{p} 110 \beta$. Both the pool of free $\mathrm{p} 85 \alpha$ subunit and the heterodimer $\mathrm{p} 85 \alpha / \mathrm{p} 110 \beta$ compete for the binding sites of IRS proteins. Thus, increased expression of $\mathrm{p} 85 \alpha$ leads to decreased PI3K activity, subsequently decreasing the sensitization to insulin [8]. P85 expression has been found to be increased in insulin-resistant human skeletal muscle and could represent an important cellular mechanism contributing to skeletal muscle insulin resistance in obesity and T2DM [7].

The association between fatty acids and insulin resistance is widely known. Its level in serum is elevated in most patients with morbid obesity, [9] with a positive association with insulin resistance [10]. Several mechanisms, such as a defect in insulin-stimulated glucose transport caused by a defect in insulin signaling [11], activation of PKC and JNK kinases, activation of TLR4 and mitochondrial dysfunction have been described to explain, in part, this association [12]. The association between dietary lipids, cell membrane phospholipid composition and insulin resistance is also known [13-16]. An inverse association was found between insulin resistance and the level of different fatty acids in the erythrocyte membrane [14]. However, elevated fatty acids levels are not always necessarily associated with insulin resistance [17]. Among other causes, this could be due to a different composition of these fatty acids [9]. Different types of fatty acids can have opposite effects, as in the case of palmitic and oleic acids [18]. Also, the involvement of different fatty acids in the IRS/PI3K signaling cascade has not been sufficiently investigated. One study found that palmitate had no effect on $\mathrm{p} 85 \alpha$ protein expression or on the activity of p110 $\beta$ [19] in myotubes. Instead, the authors found that palmitate inhibited the phosphorylation of Akt by reducing the phosphorylation of Src. In contrast, a different study found that palmitate does not alter gene expression of the insulin receptor and IRS1, but reduced its protein levels by inducing ubiquitination and proteasomal degradation of both proteins [20], and reduced the insulin-stimulated IRS-1 tyrosine phosphorylation in the myotubes from lean subjects [21].

To our knowledge, there are few studies investigating the effects of different types of fatty acids, such as palmitic (saturated), oleic (monounsaturated), linoleic (n-6 polyunsaturated) or dosahexaenoic (DHA) (n-3 polyunsaturated) acids on the gene expression of key players in the IRS1/PI3K signaling pathway in adipocytes. In the present study, we investigated the association of different fatty acids with the expression of the genes involved in this signaling cascade. 


\section{Material and Methods}

\subsection{Subjects}

We selected 18 healthy, non-obese (NO) patients (BMI $<25 \mathrm{~kg} / \mathrm{m}^{2}$ ) and 47 patients with morbid obesity (BMI $\left.>40 \mathrm{~kg} / \mathrm{m}^{2}\right), 14$ with low IR (homeostasis model assessment of insulin resistance (HOMA-IR) level < 4.7) (MO-low-IR), 24 with high IR (HOMA-IR > 4.7) (MO-high-IR) (both groups without treatment for T2DM) and 9 with T2DM under treatment with metformin (MO-metf-T2DM). The characteristics of these patients are summarized in Table 1. All patients with morbid obesity underwent laparoscopic Roux-en-Y gastric by-pass (RYGB). Subjects were excluded if they had T2DM and were receiving insulin treatment or other oral hypoglycemic medications, had cardiovascular disease, arthritis, acute inflammatory disease or infectious disease. The weight of patients with morbid obesity had been stable for at least one month before bariatric surgery. The non-obese patients underwent laparoscopic surgery for hiatus hernia or cholelithiasis, had no alterations in lipid or glucose metabolism, were of a similar age and with the same selection criteria as the patients with morbid obesity. All patients (non-obese and morbid obesity) were of Caucasian origin. Samples from subjects were processed and frozen immediately after their reception in the Regional University Hospital Biobank (Andalusian Public Health System Biobank). All the participants gave their written informed consent and the study was reviewed and approved by the Ethics and Research Committee of Regional University Hospital, Malaga, Spain (PS09/01060).

Table 1. Anthropometric and biochemical variables in patients included in the study.

\begin{tabular}{ccccc}
\hline & Non-Obese & MO-Low-IR & MO-High-IR & MO-Metf-T2DM \\
\hline$N$ (men/women) & $18(6 / 12)$ & $14(5 / 9)$ & $24(9 / 15)$ & $9(3 / 6)$ \\
Age (years) & $50.9 \pm 16.6$ & $47.8 \pm 9.5$ & $40.2 \pm 8.4^{\mathrm{a}}$ & $41.3 \pm 12.1$ \\
Weight $(\mathrm{kg})$ & $74.6 \pm 11.9$ & $140.1 \pm 29.1^{\mathrm{a}}$ & $157.7 \pm 27.2^{\mathrm{a}}$ & $141.8 \pm 22.4^{\mathrm{a}}$ \\
BMI $\left(\mathrm{kg} / \mathrm{m}^{2}\right)$ & $27.6 \pm 3.6$ & $53.4 \pm 6.4^{\mathrm{a}}$ & $56.2 \pm 6.6^{\mathrm{a}}$ & $53.1 \pm 6.0^{\mathrm{a}}$ \\
Glucose $(\mathrm{mg} / \mathrm{dl})$ & $108.0 \pm 24.3$ & $97.0 \pm 10.0$ & $112.9 \pm 36.5$ & $169.1 \pm 59.0^{\mathrm{c}}$ \\
Cholesterol $(\mathrm{mg} / \mathrm{dl})$ & $190.9 \pm 40.2$ & $199.6 \pm 42.9$ & $196.7 \pm 33.5$ & $200.5 \pm 28.9$ \\
Triglycerides $(\mathrm{mg} / \mathrm{dl})$ & $79.4 \pm 43.3$ & $109.9 \pm 39.7$ & $175.6 \pm 171.2^{\mathrm{a}}$ & $172.0 \pm 67.5$ \\
Insulin $(\mu \mathrm{IU} / \mathrm{mL})$ & $10.8 \pm 2.5$ & $14.5 \pm 1.8$ & $29.2 \pm 9.3^{\mathrm{b}}$ & $30.7 \pm 15.1^{\mathrm{b}}$ \\
HOMA-IR & $2.9 \pm 1.0$ & $3.4 \pm 0.5$ & $8.0 \pm 3.2^{\mathrm{b}}$ & $13.7 \pm 10.1^{\mathrm{c}}$ \\
Adiponectin $(\mu \mathrm{g} / \mathrm{mL})$ & $20.6 \pm 8.2$ & $12.2 \pm 4.7^{\mathrm{a}}$ & $7.9 \pm 4.1^{\mathrm{a}}$ & $7.8 \pm 4.3^{\mathrm{a}}$ \\
Leptin $(\mathrm{ng} / \mathrm{mL})$ & $10.6 \pm 3.2$ & $183.2 \pm 98.2^{\mathrm{a}}$ & $151.7 \pm 83.3^{\mathrm{a}}$ & $168.2^{\mathrm{a}} \pm 65.5^{\mathrm{a}}$ \\
\hline
\end{tabular}

The results are given as mean \pm SD. ${ }^{a} p<0.05$ significant differences with regard to non-obese group. ${ }^{\mathrm{b}} p<0.05$ significant differences with regard to non-obese and MO-low-IR. ${ }^{c} p<0.05$ significant differences with regard to non-obese, MO-low-IR and MO-high-IR.

\subsection{Biochemical Measurements}

Blood samples from all subjects were collected before surgery and after a 12-h fast. The serum was separated and immediately frozen at $-80^{\circ} \mathrm{C}$. Serum biochemical variables were measured in duplicate. Serum glucose, cholesterol and triglycerides (Randox Laboratories Ltd., Antrium, UK) were measured by standard enzymatic methods. Adiponectin levels were measured by enzyme immunoassay (ELISA) kits (DRG Diagnostics, Marburg, Germany). Leptin levels were measured by ELISA kit from Mediagnost (Reutlingen, Germany). The insulin was analyzed by an immunoradiometric assay (BioSource International, Camarillo, CA, USA). HOMA-IR was calculated with the following equation: HOMA-IR $=$ fasting insulin $(\mu \mathrm{IU} / \mathrm{mL}) \times$ fasting glucose $(\mathrm{mmol} / \mathrm{L}) / 22.5[22]$.

\subsection{Adipose Tissue Sample Collection}

Visceral adipose tissue samples from the omentum (VAT) were obtained during laparoscopic RYGB in the patients with morbid obesity $(n=47)$ and during laparoscopic surgery for hiatus hernia in the non-obese patients $(n=18)[23,24]$. The biopsy samples were washed in physiological saline 
and immediately frozen in liquid nitrogen. Biopsy samples were maintained at $-80^{\circ} \mathrm{C}$ until analysis. Additional VAT samples from MO-low-IR $(n=6)$ were placed in phosphate-buffered saline (PBS) supplemented with $5 \%$ bovine serum albumin (BSA) to perform the adipocyte isolation and in vitro incubations. We chose to carry out this experiment in this group of patients to check if different types of fatty acids could reverse the findings observed in the VAT of this group of patients. These patients had the same biochemical and anthropometric characteristics as the MO-low-IR group.

\subsection{Fatty Acid Composition of Phospholipids from Visceral Adipose Tissue}

Total lipids from frozen VAT samples were extracted with chloroform-methanol 2:1 $(v / v)$. The phospholipids were separated by thin-layer chromatography on silica gel plates (Merck, Darmstadt, Germany) with hexane-ethylic ether-acetic acid $(80: 20: 2, v / v / v)$ as the developing solvent. Phospholipids were analyzed as described [9].

\subsection{Adipocyte Culture and Fatty Acid Treatment}

VAT adipocytes were isolated by digesting freshly isolated VAT with $1 \mathrm{mg} / \mathrm{mL}$ collagenase (Worthington Biochemical Corporation, Lakewood, NJ, USA) in Dulbecco's Modified Eagle Medium (DMEM) for $1 \mathrm{~h}$ at $37{ }^{\circ} \mathrm{C}$ in a shaking water bath. Digests were filtered and centrifuged at $300 \times \mathrm{g}$ for $10 \mathrm{~min}$. Adipocytes were washed twice with DMEM and cultured in 24-well plates (50.000 adipocyte/wells) with DMEM (4.5 g/L glucose) supplemented with $10 \%$ BSA fatty acids free, $1 \% \mathrm{~L}$-glutamine, and $1 \%$ penicillin/streptomycin for $24 \mathrm{~h}$. Adipocytes were incubated with either $0.1 \mathrm{M} \mathrm{NaOH}$ (vehicle), oleic, linoleic, palmitic and DHA. Incubations with fatty acids were carried out at 25, 50 and $100 \mu \mathrm{M}[25,26]$. All four fatty acids were from Sigma-Aldrich (St. Louis, MO, USA). To prepare stock solutions, each of them was dissolved in $0.1 \mathrm{M} \mathrm{NaOH}$ at $80-90^{\circ} \mathrm{C}$. The resulting stock solutions were added to calcium-free DMEM containing 0.5\% BSA-fatty acid-free to treat the isolated adipocytes. Each treatment was performed in triplicate. Following these treatments with fatty acids for $24 \mathrm{~h}$, adipocytes were collected for mRNA isolation.

\subsection{RNA Isolation and Quantitative RT-PCR}

Total RNA from adipose tissue and adipocytes was extracted by RNeasy lipid tissue mini kit (Qiagen Science, Hilden, Germany) following the instructions of the manufacturer. cDNA was synthesized by retrotranscription using the M-MLV retrotranscriptase. Gene expression levels were analyzed in triplicate by quantitative real-time RT-PCR using a RotorGene Q Real-Time PCR system (Qiagen Science, Hilden, Germany), as previously described [27]. The primers used were designed with the online program Primer3 (http://frodo.wi.mit.edu/cgi-bin/primer3/primer3_www. cgi): IRS1 (NM_005544.2, forward: 5'-caagaccatcagcttcgtga-3', reverse: 5'-agagtcatccacctgcatcc-3'); p85 $\alpha$ (NM_181524.1, forward: 5'-accccagtttttgttgcttg-3', reverse: 5'-actgcccaacaaaaccgtcc-3'); p110 $\beta$ (NM_001256045.1, forward: 5' -ggatgttgccttatggctgt-3', reverse: 5'-ccttggagatgctgaaaagc-3'); $\beta$-actin (NM_001101.5, Fwd: 5'-tacagcttcaccaccacggc-3'; Rev: 5'-aaggaaggctggaagagtgc-3'). Gene expression was assessed using the $2^{-\Delta \Delta \mathrm{Ct}}$ method and $\beta$-actin as a reference gene.

\subsection{Statistical Analysis}

The statistical analysis was done with R statistical software, version 2.8.1 (Department of Statistics, University of Auckland, Auckland, New Zealand; http://www.r-project.org/). Differences in the mean between more than two groups were compared by the Kruskal-Wallis test. Differences between the two matched groups were analyzed by the Wilcoxon test. The Spearman correlation coefficients were calculated to estimate the associations between variables. Values were considered to be statistically significant when the $p \leq 0.05$. The results are given as the mean \pm standard deviation (SD) or mean \pm standard error of the mean (SEM) in figures. 


\section{Results}

\subsection{Fatty Acid Composition of VAT Phospholipids}

Levels of individual fatty acids from VAT phospholipids are detailed in Table 2. Compared to non-obese patients, MO-low-IR showed significantly lower levels of stearic and higher levels of vaccenic acids ( $p=0.016$ and $p=0.011$, respectively). MO-high-IR also showed significantly higher levels of vaccenic acid $(p=0.036)$, as well as higher levels of arachidonic acid $(p=0.044)$. MO-metf-T2DM only showed significantly higher levels of arachidonic acid $(p=0.014)$.

Table 2. Fatty acid composition of phospholipids in visceral adipose tissue from non-obese patients and morbid obese patients.

\begin{tabular}{|c|c|c|c|c|c|}
\hline \multicolumn{2}{|l|}{ Fatty Acid } & \multirow{2}{*}{$\begin{array}{c}\text { Non-Obese } \\
0.58 \pm 0.48\end{array}$} & \multirow{2}{*}{$\begin{array}{c}\text { MO-Low-IR } \\
0.11 \pm 0.17\end{array}$} & \multirow{2}{*}{$\begin{array}{c}\text { MO-High-IR } \\
0.25 \pm 0.38\end{array}$} & \multirow{2}{*}{$\begin{array}{c}\text { MO-Metf-TDM2 } \\
0.26 \pm 0.24\end{array}$} \\
\hline Lauric acid & $12: 0$ & & & & \\
\hline Myristic acid & 14:0 & $1.44 \pm 0.29$ & $2.18 \pm 1.78$ & $1.28 \pm 0.92$ & $1.40 \pm 1.10$ \\
\hline Palmitic acid & $16: 0$ & 22.772 .8 & $22.2 \pm 1.9$ & $22.9 \pm 3.1$ & $21.7 \pm 1.5$ \\
\hline Palmitoleic acid & $16: 1 n-7$ & $2.63 \pm 0.81$ & $2.92 \pm 1.07$ & $3.01 \pm 0.82$ & $2.41 \pm 0.49$ \\
\hline Stearic acid & $18: 0$ & $15.8 \pm 3.9$ & $12.2 \pm 2.0^{\mathrm{a}}$ & $12.8 \pm 2.2$ & $12.8 \pm 1.2$ \\
\hline Oleic acid & $18: 1 n-9$ & $30.4 \pm 4.8$ & $28.2 \pm 3.5$ & $27.9 \pm 4.6$ & $26.5 \pm 5.5$ \\
\hline Vaccenic acid & $18: 1 n-7$ & $0.94 \pm 1.33$ & $2.62 \pm 0.55^{\mathrm{a}}$ & $2.35 \pm 1.38^{a}$ & $2.10 \pm 1.04$ \\
\hline Linoleic acid & $18: 2 n-6$ & $16.1 \pm 4.5$ & $17.8 \pm 2.0$ & $14.7 \pm 3.5$ & $16.4 \pm 3.0$ \\
\hline Gamma-linolenic acid & $18: 3 n-6$ & $0.03 \pm 0.08$ & $0.02 \pm 0.06$ & $0.07 \pm 0.27$ & $0.01 \pm 0.01$ \\
\hline$\alpha$-Linoleic acid & $18: 3 n-3$ & $0.29 \pm 0.32$ & $0.54 \pm 0.84$ & $0.28 \pm 0.38$ & $0.55 \pm 0.54$ \\
\hline Eicosanoic acid & $20: 0$ & $1.01 \pm 0.50$ & $0.54 \pm 0.54$ & $1.09 \pm 1.06$ & $1.29 \pm 0.51$ \\
\hline Gondoic acid & $20: 1 n-9$ & $0.80 \pm 0.61$ & $0.89 \pm 0.34$ & $1.12 \pm 1.79$ & $1.13 \pm 0.58$ \\
\hline Eicosadienoic acid & $20: 2 n-6$ & $0.47 \pm 0.51$ & $0.73 \pm 0.59$ & $0.62 \pm 1.06$ & $0.87 \pm 0.60$ \\
\hline Dihomo-gamma-linolenic acid & $20: 3 n-6$ & $0.73 \pm 0.34$ & $1.17 \pm 0.57$ & $1.32 \pm 1.33$ & $1.79 \pm 0.86$ \\
\hline Arachidonic acid & $20: 4 n-6$ & $4.18 \pm 1.48$ & $5.62 \pm 1.39$ & $6.33 \pm 1.99^{a}$ & $7.24 \pm 2.28^{a}$ \\
\hline Eicosatrienoic acid & $20: 3 n-3$ & $0.05 \pm 0.09$ & $0.14 \pm 0.28$ & $0.33 \pm 0.24$ & $0.18 \pm 0.20$ \\
\hline Eicosapentaenoic acid & $20: 5 n-3$ & $0.35 \pm 0.29$ & $0.27 \pm 0.32$ & $0.50 \pm 0.63$ & $1.04 \pm 1.49$ \\
\hline Adrenic acid & $22: 4 n-6$ & $0.37 \pm 0.35$ & $0.72 \pm 0.55$ & $1.01 \pm 1.03$ & $0.68 \pm 0.47$ \\
\hline Docosapentaenoic acid & $22: 5 n-3$ & $0.24 \pm 0.27$ & $0.23 \pm 0.35$ & $0.65 \pm 0.86$ & $0.49 \pm 0.48$ \\
\hline Docosahexaenoic acid & $22: 6 n-3$ & $0.61 \pm 0.98$ & $0.80 \pm 0.64$ & $0.77 \pm 1.01$ & $1.08 \pm 0.74$ \\
\hline \multicolumn{2}{|c|}{ Total saturated fatty acids } & $41.6 \pm 5.9$ & $37.2 \pm 3.7$ & $38.9 \pm 5.0$ & $37.4 \pm 2.3$ \\
\hline \multicolumn{2}{|c|}{ Total monounsaturated fatty acids } & $34.7 \pm 4.8$ & $34.6 \pm 4.0$ & $34.4 \pm 5.1$ & $32.2 \pm 5.5$ \\
\hline \multicolumn{2}{|c|}{ n-3 polyunsaturated fatty acids } & $1.54 \pm 1.45$ & $1.99 \pm 1.28$ & $2.54 \pm 2.34$ & $3.35 \pm 3.11$ \\
\hline \multicolumn{2}{|c|}{ n-6 polyunsaturated fatty acids } & $22.0 \pm 5.1$ & $26.0 \pm 2.1$ & $24.1 \pm 4.9$ & $26.9 \pm 3.7$ \\
\hline
\end{tabular}

Results are represented as mean \pm SD. ${ }^{\text {a }} p<0.05$ significant differences with regard to the non-obese patients.

\subsection{IRS1, $p 85 \alpha$ and $p 110 \beta$ Gene Expression}

Analysis of the gene expression of key players of the IRS1/PI3K signaling cascade (Figure 1) showed a reduced expression of IRS1 in all three groups of patients with morbid obesity compared to non-obese patients, with only the MO-low-IR and MO-high-IR groups showing significant differences $(p=0.017$ and $p=0.02$, respectively). $\mathrm{p} 110 \beta$ was decreased in the three groups of morbidly obese patients, with only the MO-low-IR group showing significant differences $(p=0.036)$. There were no significant differences in $\mathrm{p} 85 \alpha$ expression and $\mathrm{p} 85 / \mathrm{p} 110 \beta$ ratio. 

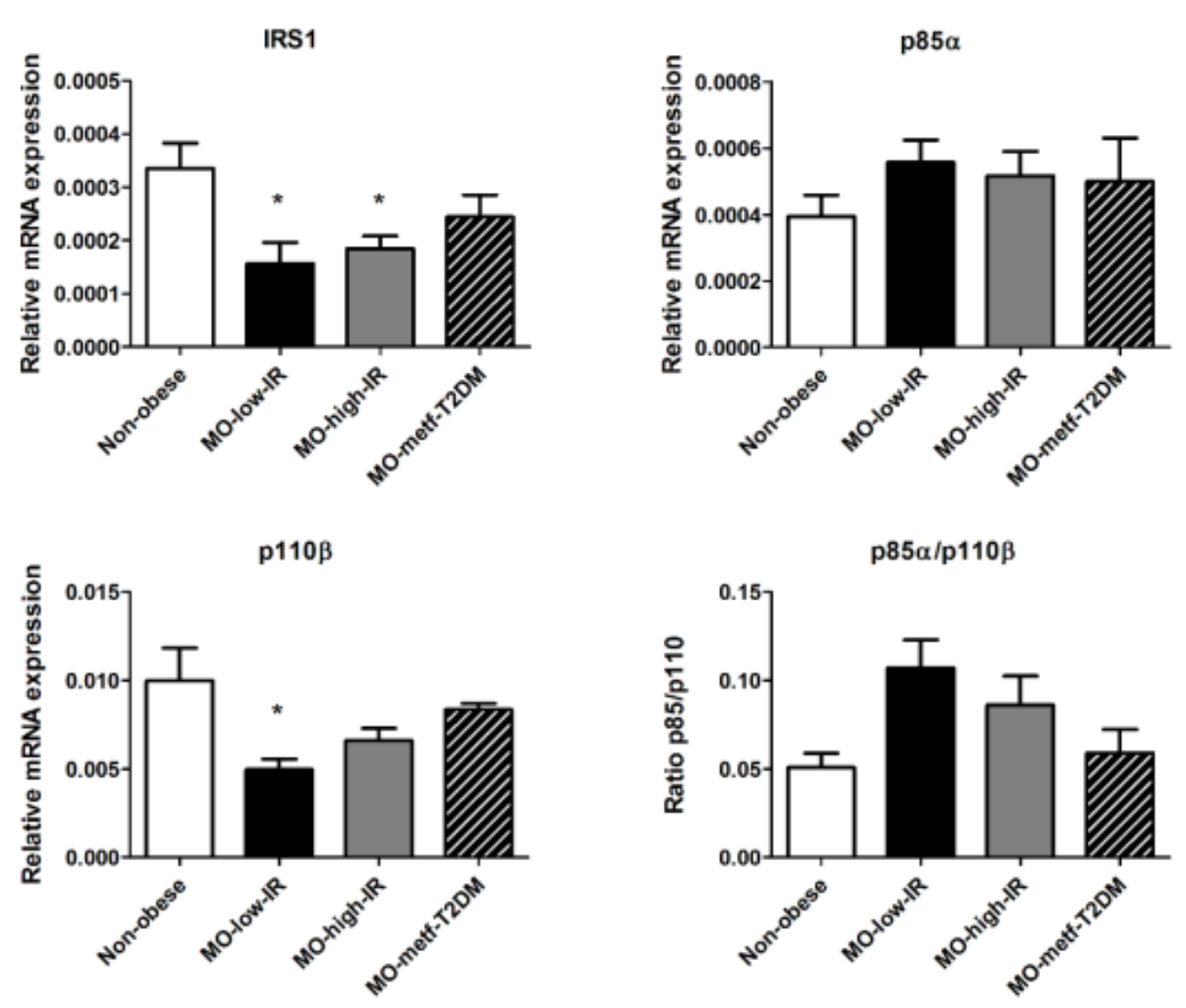

Figure 1. mRNA expression levels of IRS1, $\mathrm{p} 85 \alpha, \mathrm{p} 110 \beta$ and $\mathrm{p} 85 \alpha / \mathrm{p} 110 \beta$ ratio in VAT from non-obese patients and in patients with morbid obesity with low insulin resistance (MO-low-IR), with high insulin resistance (MO-high-IR), and with T2DM under treatment with metformin (MO-metf-T2DM). Gene expression was assessed using the $2^{-\Delta \Delta C t}$ method. Results are represented as mean \pm SEM. ${ }^{*} p<0.05$ with regard to non-obese patients.

\subsection{Association between VAT Phospholipid Composition and mRNA Expression}

First, we wanted to know whether the levels of a particular fatty acid could be associated with the gene expression of IRS1, p $85 \alpha$ or p110 $\beta$, taking into account all patients (non-obese patients and those with morbid obesity) (Table 3). We found a significant positive correlation between p85 $\alpha$ and both stearic and total saturated fatty acids. In contrast, $\mathrm{p} 85 \alpha$ negatively correlated with oleic acid and total unsaturated fatty acids. Both IRS1 and p110 $\beta$ negatively correlated with the sum of all n- 6 fatty acids, linoleic, arachidonic, and adrenic acid. In contrast, IRS1 and p110 $\beta$ positively correlated with palmitic and DHA. The ratio p $85 \alpha / \mathrm{p} 110 \beta$ was not correlated with any of the fatty acids assessed. However, no significant differences were found between gene expression of IRS1, p85 $\alpha$ or p110 $\beta$, and HOMA-IR and other biochemical variables described in Table 1. 
Table 3. Significant correlations $(p)$ between the fatty acid composition of phospholipids and mRNA expression of IRS1, $\mathrm{p} 85 \alpha, \mathrm{p} 110 \beta$ and $\mathrm{p} 85 \alpha / \mathrm{p} 110 \beta$ ratio in visceral adipose tissue.

\begin{tabular}{|c|c|c|c|c|c|}
\hline \multicolumn{2}{|l|}{ Fatty Acid } & \multirow{2}{*}{$\begin{array}{c}\text { IRS1 } \\
r=0.353 \\
p=0.017\end{array}$} & \multirow{2}{*}{$\begin{array}{c}\text { p85 } \alpha \\
r=0.234 \\
p=0.126\end{array}$} & \multirow{2}{*}{$\begin{array}{c}\text { p110 } \beta \\
r=0.372 \\
p=0.012\end{array}$} & \multirow{2}{*}{$\begin{array}{c}\mathrm{p} 85 / \mathbf{p} \mathbf{1 1 0} \beta \\
r=0.033 \\
p=0.833\end{array}$} \\
\hline Palmitic acid & $16: 0$ & & & & \\
\hline Stearic acid & 18:0 & $\begin{array}{l}r=0.103 \\
p=0.501\end{array}$ & $\begin{array}{l}r=0.484 \\
p=0.001\end{array}$ & $\begin{array}{c}r=-0.179 \\
p=0.240\end{array}$ & $\begin{array}{c}r=-0.152 \\
p=0.329\end{array}$ \\
\hline Oleic acid & $18: 1 n-9$ & $\begin{array}{l}r=0.284 \\
p=0.059\end{array}$ & $\begin{array}{c}r=-0.364 \\
p=0.015\end{array}$ & $\begin{array}{l}r=0.303 \\
p=0.043\end{array}$ & $\begin{array}{l}r=0.294 \\
p=0.056\end{array}$ \\
\hline Linoleic acid & $18: 2 n-6$ & $\begin{array}{c}r=-0.416 \\
p=0.004\end{array}$ & $\begin{array}{c}r=-0.246 \\
p=0.108\end{array}$ & $\begin{array}{c}r=-0.348 \\
p=0.019\end{array}$ & $\begin{array}{l}r=0.048 \\
p=0.762\end{array}$ \\
\hline Arachidonic acid & $20: 4 n-6$ & $\begin{array}{c}r=-0.296 \\
p=0.049\end{array}$ & $\begin{array}{c}r=-0.123 \\
p=0.426\end{array}$ & $\begin{array}{c}r=-0.310 \\
p=0.038\end{array}$ & $\begin{array}{c}r=-0.063 \\
p=0.687\end{array}$ \\
\hline Adrenic acid & $22: 4 n-6$ & $\begin{array}{c}r=-0.305 \\
p=0.041\end{array}$ & $\begin{array}{c}r=-0.139 \\
p=0.367\end{array}$ & $\begin{array}{c}r=-0.171 \\
p=0.261\end{array}$ & $\begin{array}{c}r=-0.083 \\
p=0.599\end{array}$ \\
\hline Docosahexaenoic acid & $22: 6 n-3$ & $\begin{array}{l}r=0.335 \\
p=0.025\end{array}$ & $\begin{array}{c}r=-0.211 \\
p=0.170\end{array}$ & $\begin{array}{l}r=0.543 \\
p<0.001\end{array}$ & $\begin{array}{l}r=0.145 \\
p=0.354\end{array}$ \\
\hline \multicolumn{2}{|c|}{ Total saturated fatty acids } & $\begin{array}{l}r=0.221 \\
p=0.144\end{array}$ & $\begin{array}{l}r=0.446 \\
p=0.002\end{array}$ & $\begin{array}{l}r=0.044 \\
p=0.775\end{array}$ & $\begin{array}{c}r=-0.047 \\
p=0.764\end{array}$ \\
\hline \multicolumn{2}{|c|}{ Total unsaturated fatty acids } & $\begin{array}{c}r=-0.221 \\
p=0.144\end{array}$ & $\begin{array}{c}r=-0.446 \\
p=0.002\end{array}$ & $\begin{array}{c}r=-0.044 \\
p=0.775\end{array}$ & $\begin{array}{l}r=0.047 \\
p=0.764\end{array}$ \\
\hline \multicolumn{2}{|c|}{ n-6 polyunsaturated fatty acids } & $\begin{array}{c}r=-0.587 \\
p<0.001\end{array}$ & $\begin{array}{c}r=-0.266 \\
p=0.081\end{array}$ & $\begin{array}{c}r=-0.497 \\
p=0.001\end{array}$ & $\begin{array}{c}r=-0.062 \\
p=0.691\end{array}$ \\
\hline
\end{tabular}

\subsection{In Vitro Response to Fatty Acids}

To assess a direct effect of these fatty acids on the gene expression of IRS1, p $85 \alpha$ and p110, we investigated in vitro the effects of the main fatty acids that were significant in the correlations shown above: Palmitic (saturated fatty acid), oleic (monounsaturated fatty acid), linoleic (n-6 polyunsaturated fatty acid), and DHA (n-3 polyunsaturated fatty acid). Accordingly, we incubated freshly isolated adipocytes from VAT during $24 \mathrm{~h}$ with each of these fatty acids at different concentrations (Figure 2). With regard to IRS1, only the incubation with palmitic acid decreased its expression compared to control $(p=0.043$ for both $50 \mu \mathrm{M}$ and $100 \mu \mathrm{M})$. Palmitic acid also decreased IRS1 expression in a dose-dependent manner $(p=0.043$ between $25 \mu \mathrm{M}$ and $50 \mu \mathrm{M}$, and $p=0.043$ between $25 \mu \mathrm{M}$ and $100 \mu \mathrm{M})$. Oleic acid increased IRS1 expression in a dose-dependent manner, but not significantly ( $p=0.068$ for tests between the three different doses). Linoleic acid decreased IRS1 expression in a dose-dependent manner, but not significantly ( $p=0.068$ for both 50 and $100 \mu \mathrm{M}$ compared to the control, and $p=0.068$ for tests between the three different doses).

With regard to $\mathrm{p} 85 \alpha$ (Figure 2), oleic acid decreased its expression in a dose-dependent manner $(p=0.028$ for all three doses with regard to the control; $p=0.028$ between $25 \mu \mathrm{M}$ and $50 \mu \mathrm{M} ; p=0.028$ between $25 \mu \mathrm{M}$ and $100 \mu \mathrm{M}$; and $p=0.046$ between $50 \mu \mathrm{M}$ and $100 \mu \mathrm{M}$ ). Linoleic acid decreased p85 $\alpha$ expression, but only at $25 \mu \mathrm{M}(p=0.012)$ and $100 \mu \mathrm{M}(p=0.018)$. DHA also decreased p85 $\alpha$ expression in a dose-dependent manner $(p=0.025$ for $25 \mu \mathrm{M}, p=0.036$ for $50 \mu \mathrm{M}$ and $p=0.012$ for $100 \mu \mathrm{M}$ with regard to the control; $p=0.017$ between $25 \mu \mathrm{M}$ and $100 \mu \mathrm{M}$; and $p=0.012$ between $50 \mu \mathrm{M}$ and $100 \mu \mathrm{M}$ ). Also, palmitic acid increased p85 expression with $100 \mu \mathrm{M}$ with regard to $25 \mu \mathrm{M}$ and $50 \mu \mathrm{M}(p=0.050$ and $p=0.012$, respectively).

Oleic acid also showed a dose-dependent effect on p110 $\beta$ expression (Figure 2), with the lower dose leading to significantly reduced levels of $\mathrm{p} 110 \beta(p=0.018)$, but increasing significantly with higher doses ( $p=0.018$ for tests between the three different doses). $50 \mu \mathrm{M}$ and $100 \mu \mathrm{M}$ did not show 
significant differences with regard to the control. Also, $100 \mu \mathrm{M}$ of palmitic acid significantly decreased p110 $\beta$ expression with regard to $25 \mu \mathrm{M}$ and $50 \mu \mathrm{M}$ ( $p=0.043$ and $p=0.043$, respectively).
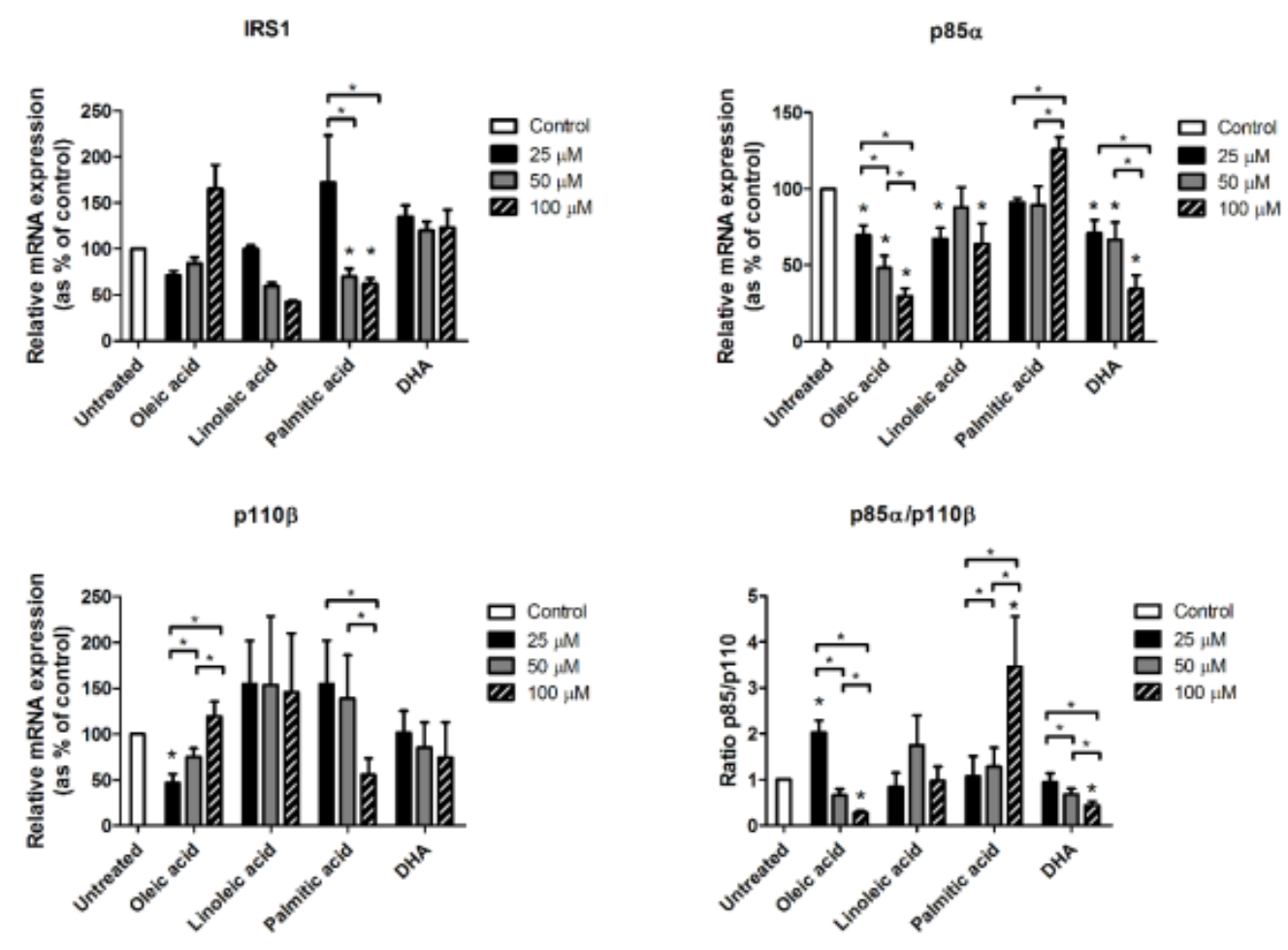

Figure 2. mRNA expression levels of IRS1, p85 $\alpha, \mathrm{p} 110 \beta$ and $\mathrm{p} 85 \alpha / \mathrm{p} 110 \beta$ ratio from isolated visceral adipocytes incubated with oleic, linoleic, palmitic and dosahexaenoic (DHA) acids. For each fatty acid, incubations were made with 25,50 and $100 \mu \mathrm{M}$ dose. Gene expression was assessed using the $2^{-\Delta \Delta C t}$ method, which was converted as $\%$ of control (untreated). Results are represented as mean \pm SEM. ${ }^{*} p<0.05$ comparing each treatment and dose to the untreated sample (stars over bars) and between different doses inside each treatment group.

The $\mathrm{p} 85 \alpha / \mathrm{p} 110 \beta$ ratio (Figure 2) significantly increased with $25 \mu \mathrm{M}$ of oleic acid $(p=0.043)$, but was further down-regulated with $50 \mu \mathrm{M}$ and $100 \mu \mathrm{M}$ doses $(p=0.043$ for tests between the three different doses), reaching significantly reduced levels with regard to the control $(p=0.043)$. Similar to oleic acid, DHA also led to a dose-dependent down-regulation of $\mathrm{p} 85 \alpha / \mathrm{p} 110 \beta$ ratio $(p=0.043$ for $100 \mu \mathrm{M}$ with regard to the control; $p=0.043$ between $25 \mu \mathrm{M}$ and $50 \mu \mathrm{M}$; and $p=0.043$ between $25 \mu \mathrm{M}$ and $100 \mu \mathrm{M})$. The p $85 \alpha / \mathrm{p} 110 \beta$ ratio was dramatically increased with $100 \mu \mathrm{M}$ of palmitic acid $(p=0.043$ with regard to the control, and $p=0.043$ for tests between the three different doses).

\section{Discussion}

The main result of this study was the different effect observed in the incubations with different types of fatty acids on the expression of genes involved in IRS1/PI3K pathway in visceral adipocytes. We observed a down-regulation of IRS1 and an increased $\mathrm{p} 85 \alpha / \mathrm{p} 110 \beta$ ratio with palmitic acid. However, oleic acid decreased $\mathrm{p} 85 \alpha$ expression and the $\mathrm{p} 85 \alpha / \mathrm{p} 110 \beta$ ratio, and increased $\mathrm{p} 110 \beta$. DHA had a moderate effect only on $\mathrm{p} 85 \alpha$ expression and the $\mathrm{p} 85 \alpha / \mathrm{p} 110 \beta$ ratio, and linoleic acid was the one with the least effect in visceral adipocytes.

Obesity and insulin resistance/T2DM are associated with an imbalance in the PI3K/AKT signaling pathway [28]. As in previous studies [29,30], we found decreased levels of IRS1 VAT from patients with morbid obesity, independent of the insulin-resistant state, with metformin slightly increasing IRS1 expression. Different studies in human show that there is a decrease in IRS1 protein in the 
insulin-resistant human skeletal muscle [7], in obese muscle [31], and in adipose tissue of patients with T2DM [32]. Similar results were found in a study in the Zucker fatty rat model, in which insulin resistance was associated with a decreased levels of IRS proteins [33]. Also, our results showed a decrease of $\mathrm{p} 110 \beta$ and a slight increase, although not significant, of $\mathrm{p} 85 \alpha$ expression and the $\mathrm{p} 85 \alpha / \mathrm{p} 110 \beta$ ratio, as in other studies in an insulin resistant state [7,34,35]. Our results with $p 110 \beta$ agree with another study in which a decrease of p110 and IRS1 was observed in the muscle of insulin-resistant subjects [7]. However, elevated levels of protein p85 was a feature of insulin resistance in human skeletal muscle [7]. Cornier et al. also showed that three days of overfeeding ( $50 \%$ above usual caloric intake) significantly increased p85 $\alpha, \mathrm{p} 85 / \mathrm{p} 110$ ratio and insulin resistance in human skeletal muscle [36]. Studies in animals with a disruption of $\mathrm{p} 85 \alpha$ (p85 $5^{+/-}$heterozygous mice) showed a higher ratio of $\mathrm{p} 85 / \mathrm{p} 110$ dimer to free p85 and were more sensitive to insulin [37].

High fatty acid levels have been commonly known to be associated with the development of IR [38]. However, not all individual fatty acids have the same effect. In fact, palmitic and oleic acid have been described as having the opposite roles in the development of IR [1]. Therefore, palmitic acid is known to induce IR through a variety of mechanisms [20,39]. Moreover, we demonstrated in a previous study that palmitic acid increases the inflammation markers in visceral adipocytes [26]. Palmitic acids also reduced the insulin-stimulated IRS- 1 tyrosine phosphorylation in the myotubes from lean subjects [21], and increased insulin resistance in C2C12 skeletal muscle cells [40]. In contrast, oleic acid has been described to protect from IR [41]. In rodent muscle, oleic acid promoted GLUT4 through the PI3K pathway, preventing the effects of palmitic acid [42]. There are different mechanisms by which oleic acid prevents IR, such as reducing ER and mitochondrial stress, increasing mitochondrial $\beta$-oxidation and preventing inflammation $[26,41,43,44]$.

However, the impact of each type of fatty acid (saturated, monounsaturated, n- 6 and n-3 polyunsaturated) on the mRNA expression of IRS1 and PI3K subunits, which are key players in the metabolic response to insulin, have not been thoroughly assessed. To analyze that impact, we have analyzed the possible association between the fatty acid composition of VAT phospholipid with the expression of IRS1, p $85 \alpha$ and p110 $\beta$, and we further replicated the most relevant results in incubations of VAT adipocytes. Although the positive correlation between palmitic acid and IRS1 may contradict previous studies reporting the harmful effects of palmitic acid on IR, the dose-dependent down-regulation of IRS1 in response to palmitic acid observed in in vitro-cultured adipocytes suggests that IRS1 is down-regulated by this fatty acid. This result would agree with previous studies showing that palmitic acid induces IR [39]. The in vivo association may be affected by other factors not considered in this study, the final result of which could mask the relationship between palmitic acid and IRS1 expression. The downregulation of the in vivo IRS1 levels could be due to other molecules, such as $\mathrm{TNF} \alpha$, glucocorticoid and mineralocorticoid, which are increased in obesity [45-48]. We also found that other fatty acids positively correlated with IRS1 expression, such as oleic acid and DHA. However, neither of these two fatty acids produced a significant increase in the expression of IRS1, although this trend was observed with oleic acid. Regarding linoleic acid, its levels negatively correlated with IRS1 expression. Despite the lack of statistically significant results from in vitro-cultured adipocytes, we found a dose-dependent effect on IRS1 expression that was close to being significant. This suggests that this gene would, in fact, be down-regulated by linoleic acid, confirming the harmful effects of $n-6$ fatty acids on insulin sensitivity [49].

The increased expression of $\mathrm{p} 85 \alpha$ has been suggested to be an early molecular step in the pathogenesis of nutritionally induced insulin resistance [1]. Previous reports have not observed any effects of palmitic acid on p85 $\alpha$ protein expression [19]. Likewise, we did not observe a correlation between palmitic acid and p85 $\alpha$, although we observed an up-regulation at the higher dose used. In contrast, oleic acid negatively correlated with $\mathrm{p} 85 \alpha$, which was further confirmed in in vitro-cultured adipocytes, with a dose-dependent down-regulation of $\mathrm{p} 85 \alpha$. This down-regulation of $\mathrm{p} 85 \alpha$ would increase the pool of $\mathrm{p} 85 \alpha / \mathrm{p} 110 \beta$ dimer available to bind to IRS1, therefore, increasing insulin sensitivity [1]. Therefore, our results suggest that oleic acid would have a beneficial effect in 
protecting from IR. DHA also down-regulated $\mathrm{p} 85 \alpha$, more dramatically at the higher dose. This effect was also observed in the correlation analysis, although it did not reach statistical significance. This down-regulation may also explain the protection of n-3 fatty acids to IR described in the literature [50].

The other PI3K subunit studied is p110ß. Its expression in VAT positively correlated with palmitic, oleic and DHA. However, p110 $\beta$ expression in in vitro-cultured adipocytes only showed a significant increased in a dose-dependent manner with higher concentrations of oleic acid. Palmitic acid also positively correlated with $\mathrm{p} 110 \beta$, although incubations showed a significant decrease of $\mathrm{p} 110 \beta$ expression with the higher dose. This discordance is similar to those found for IRS1. Specifically, correlations with palmitic acid could be affected by confounder factors not controlled in this study; alternatively, the effect of another fatty acid could prevail for the effects of palmitic acid. Further studies are necessary to confirm this hypothesis.

Together, the expressions of $\mathrm{p} 85 \alpha$ and $\mathrm{p} 110 \beta$ could be affecting insulin signaling. $\mathrm{p} 85 \alpha / \mathrm{p} 110 \beta$ heterodimer is responsible for the PI3K activity. Although the $\mathrm{p} 85 \alpha / \mathrm{p} 110 \beta$ ratio did not initially correlate with any fatty acid, we observed different effects depending on the type of fatty acid. DHA and mainly oleic acid decreased the $\mathrm{p} 85 \alpha / \mathrm{p} 110 \beta$ ratio in a dose-dependent manner. A decrease of $\mathrm{p} 85 \alpha / \mathrm{p} 110 \beta$ ratio means lower free $\mathrm{p} 85 \alpha$ to compete with the $\mathrm{p} 85 \alpha / \mathrm{p} 110 \beta$ monomer for the binding sites of IRS proteins. However, palmitic acid increased this ratio. An increase of $\mathrm{p} 85 \alpha / \mathrm{p} 110 \beta$ ratio [51] could cause an alteration of PI3K activity.

However, this study has several limitations. The effect of a single fatty acid does not represent the in vivo situation, which is a mixture of the effects of different types of fatty acids. Other studies use a coculture model with adipocytes and myotubes [52] to resemble in vivo physiology conditions. However, in our study, we wanted to separate the effects that each fatty acid may have on the expression of genes related to IRS1/PI3K pathways. Also, we have used this type of adipose tissue (VAT) because it is more associated with insulin resistance than other types of adipose tissue [53]. Another limitation refers to the type of subjects. Lipid metabolism can be highly dependent on ethnicity $[54,55]$. We limited our study to the Caucasian ethnicity because of lack of availability of samples from subjects from other ethnicities. Also, we obtained neither sufficient visceral adipocytes to measure the effects of other fatty acids that were differentially expressed between non-obese patients and those with morbid obesity, such as vaccenic and stearic acids, nor all the protein, phosphorylation levels and function of the genes studied. Adipocytes were only used for mRNA isolation. We think that the genes studied may be the most interesting ones involved in IRS1/PI3K pathways. However, other proteins are also involved, and it would have been interesting to study the effect of these fatty acids on their expression. Further studies are needed to analyze this and other aspects.

In conclusion, although changes in gene expression do not necessarily equate to changes in protein content or function, fatty acid-induced regulation of the genes involved in the IRS1/PI3K pathway may be a novel mechanism by which fatty acids regulate insulin sensitivity in visceral adipocytes. As expected, the impact of each fatty acid on the expression of key components of the IRS1/PI3K pathway is different. Most of the metabolic responses to insulin depend upon the activation of the IRS1/PI3K pathway. Overall, our in vitro results suggest a detrimental role of palmitic acid on the expression of gene related to insulin signaling pathway, being oleic acid the one with the higher and more beneficial effects. This effect of oleic acid subsequently would enhance insulin sensitivity. DHA showed a moderately beneficial effect, and linoleic acid was the one with the least effect on the insulin signaling pathway in visceral adipocytes. Further studies are needed to analyze other genes not studied in this work or to study the effects of each fatty acid on different types of adipose tissue and other tissues involved in the regulation of insulin resistance, such as muscle and liver. This will provide further evidence of the role of these fatty acids on the insulin signaling pathway. Also, it would be interesting to analyze the fatty acids composition of other lipids, such as diacylglycerides and acylcarnitines, which could be involved in the regulation of insulin resistance. 
Author Contributions: Conceptualization, E.G.-F. and F.R.-P.; methodology, E.G.-F., S.G.-S., E.G.-E., C.G.-R., C.R.-D., A.H.-P., F.M.-R., S.V. and A.R.-C.; formal analysis, C.L.-G., C.S.-F., C.G.-R., L.G.-S. and E.G.-F.; investigation F.R.-P., E.G.-E. and E.G.-F.; writing-review and editing, C.L.-G., C.S.-F. and E.G.-F.; supervision, E.G.-F.; All authors have read and agreed to the published version of the manuscript

Funding: This work was supported in part by a grant from the Instituto de Salud Carlos III, Spain (PI09/01016), and from a grant of the Consejería de Economía, Innovación y Ciencia de la Junta de Andalucía, Spain (CTS8081). This study has been co-funded by FEDER funds ("A way to make Europe") ("Andalucía se mueve con Europa"). CIBER Fisiopatología de la Obesidad y Nutrición (CIBEROBN) and CIBER de Diabetes y Enfermedades Metabólicas Asociadas (CIBERDEM) are ISCIII projects. all authors have read the journal's authorship statement. CLG is supported by a grant from the Ministerio de Educación y Formación Professional (Spain) (IJCI-2017-31466). CSF is supported by a grant from the ISCIII (Spain) (FI16/00241). CGR is supported by a grant from the Ministerio de Educación y Formación Professional (Spain) (IJCI-2017-33065). CRD is supported by a grant from the ISCIII (Spain) (CD18/00188). AHP is supported by a grant from the Ministerio de Educación y Formación Professional (Spain) (FPU14/01972). FMR is supported by a grant from the ISCIII (Spain) ("PFIS" program, FI19/00189). LGS is supported by the Miguel Servet program from the ISCIII (Spain) ("Miguel Servet II" program, CPII18/00030) and Nicolas Monardes program from the Consejería de Salud de Andalucía (Spain) (C-0028-2018). FRP is supported by the Miguel Servet program from the ISCIII (Spain) ("Miguel Servet I" program, CP18/00042). EGF is supported by the Nicolas Monardes program from the Consejería de Salud de Andalucía (Spain) (C-0031-2016).

Conflicts of Interest: The authors declare no conflict of interest.

\section{References}

1. Draznin, B. Molecular mechanisms of insulin resistance: Serine phosphorylation of insulin receptor substrate-1 and increased expression of p85alpha: The two sides of a coin. Diabetes 2006, 55, 2392-2397. [CrossRef] [PubMed]

2. White, M.F. The insulin signalling system and the IRS proteins. Diabetologia 1997, 40 (Suppl. S2), S2-S17. [CrossRef] [PubMed]

3. Araki, E.; Lipes, M.A.; Patti, M.E.; Bruning, J.C.; Haag, B., 3rd; Johnson, R.S.; Kahn, C.R. Alternative pathway of insulin signalling in mice with targeted disruption of the IRS-1 gene. Nature 1994, 372, 186-190. [CrossRef] [PubMed]

4. Withers, D.J.; Gutierrez, J.S.; Towery, H.; Burks, D.J.; Ren, J.M.; Previs, S.; Zhang, Y.; Bernal, D.; Pons, S.; Shulman, G.I.; et al. Disruption of IRS-2 causes type 2 diabetes in mice. Nature 1998, 391, 900-904. [CrossRef]

5. Asano, T.; Fujishiro, M.; Kushiyama, A.; Nakatsu, Y.; Yoneda, M.; Kamata, H.; Sakoda, H. Role of phosphatidylinositol 3-kinase activation on insulin action and its alteration in diabetic conditions. Biol. Pharm. Bull. 2007, 30, 1610-1616. [CrossRef]

6. Qiao, L.Y.; Goldberg, J.L.; Russell, J.C.; Sun, X.J. Identification of enhanced serine kinase activity in insulin resistance. J. Biol. Chem. 1999, 274, 10625-10632. [CrossRef]

7. Bandyopadhyay, G.K.; Yu, J.G.; Ofrecio, J.; Olefsky, J.M. Increased p85/55/50 expression and decreased phosphotidylinositol 3-kinase activity in insulin-resistant human skeletal muscle. Diabetes 2005, 54, 2351-2359. [CrossRef]

8. Ueki, K.; Algenstaedt, P.; Mauvais-Jarvis, F.; Kahn, C.R. Positive and negative regulation of phosphoinositide 3-kinase-dependent signaling pathways by three different gene products of the p85alpha regulatory subunit. Mol. Cell. Biol. 2000, 20, 8035-8046. [CrossRef]

9. Soriguer, F.; Garcia-Serrano, S.; Garcia-Almeida, J.M.; Garrido-Sanchez, L.; Garcia-Arnes, J.; Tinahones, F.J.; Cardona, I.; Rivas-Marín, J.; Gallego-Perales, J.L.; García-Fuentes, E. Changes in the serum composition of free-fatty acids during an intravenous glucose tolerance test. Obesity 2009, 17, 10-15. [CrossRef]

10. Boden, G.; Chen, X.; Ruiz, J.; White, J.V.; Rossetti, L. Mechanisms of fatty acid-induced inhibition of glucose uptake. J. Clin. Investig. 1994, 93, 2438-2446. [CrossRef]

11. Boden, G.; Chen, X. Effects of fat on glucose uptake and utilization in patients with non-insulin-dependent diabetes. J. Clin. Investig. 1995, 96, 1261-1268. [CrossRef] [PubMed]

12. Yazici, D.; Sezer, H. Insulin Resistance, Obesity and Lipotoxicity. Adv. Exp. Med. Biol. 2017, 960, $277-304$.

13. Riccardi, G.; Giacco, R.; Rivellese, A.A. Dietary fat, insulin sensitivity and the metabolic syndrome. Clin. Nutr. 2004, 23, 447-456. [CrossRef] [PubMed]

14. Thorseng, T.; Witte, D.R.; Vistisen, D.; Borch-Johnsen, K.; Bjerregaard, P.; Jørgensen, M.E. The association between $n-3$ fatty acids in erythrocyte membranes and insulin resistance: The Inuit Health in Transition Study. Int. J. Circumpolar Health 2009, 68, 327-336. [CrossRef] [PubMed] 
15. Gunes, O.; Tascilar, E.; Sertoglu, E.; Tas, A.; Serdar, M.A.; Kaya, G.; Kayadibi, H.; Ozcan, O. Associations between erythrocyte membrane fatty acid compositions and insulin resistance in obese adolescents. Chem. Phys. Lipids 2014, 184, 69-75. [CrossRef]

16. Haag, M.; Dippenaar, N.G. Dietary fats, fatty acids and insulin resistance: Short review of a multifaceted connection. Med. Sci. Monit. 2005, 11, RA359-RA367.

17. Karpe, F.; Dickmann, J.R.; Frayn, K.N. Fatty acids, obesity, and insulin resistance: Time for a reevaluation. Diabetes 2011, 60, 2441-2449. [CrossRef]

18. Palomer, X.; Pizarro-Delgado, J.; Barroso, E.; Vazquez-Carrera, M. Palmitic and Oleic Acid: The Yin and Yang of Fatty Acids in Type 2 Diabetes Mellitus. Trends Endocrinol. Metab. TEM 2018, 29, 178-190. [CrossRef]

19. Feng, X.T.; Wang, T.Z.; Leng, J.; Chen, Y.; Liu, J.B.; Liu, Y.; Wang, W.-J. Palmitate contributes to insulin resistance through downregulation of the Src-mediated phosphorylation of Akt in C2C12 myotubes. Biosci. Biotechnol. Biochem. 2012, 76, 1356-1361. [CrossRef]

20. Ishii, M.; Maeda, A.; Tani, S.; Akagawa, M. Palmitate induces insulin resistance in human HepG2 hepatocytes by enhancing ubiquitination and proteasomal degradation of key insulin signaling molecules. Arch. Biochem. Biophys. 2015, 566, 26-35. [CrossRef]

21. Bikman, B.T.; Zheng, D.; Reed, M.A.; Hickner, R.C.; Houmard, J.A.; Dohm, G.L. Lipid-induced insulin resistance is prevented in lean and obese myotubes by AICAR treatment. Am. J. Physiol. Regul. Integr. Comp. Physiol. 2010, 298, R1692-R1699. [CrossRef] [PubMed]

22. Matthews, D.R.; Hosker, J.P.; Rudenski, A.S.; Naylor, B.A.; Treacher, D.F.; Turner, R.C. Homeostasis model assessment: Insulin resistance and beta-cell function from fasting plasma glucose and insulin concentrations in man. Diabetologia 1985, 28, 412-419. [CrossRef]

23. Tinahones, F.J.; Garrido-Sanchez, L.; Miranda, M.; Garcia-Almeida, J.M.; Macias-Gonzalez, M.; Ceperuelo, V.; Gluckmann, E.; Rivas-Marin, J.; Vendrell, J.; García-Fuentes, E. Obesity and insulin resistance-related changes in the expression of lipogenic and lipolytic genes in morbidly obese subjects. Obes. Surg. 2010, 20, 1559-1567. [CrossRef] [PubMed]

24. Garcia-Serrano, S.; Moreno-Santos, I.; Garrido-Sanchez, L.; Gutierrez-Repiso, C.; Garcia-Almeida, J.M.; Garcia-Arnes, J.; Rivas-Marín, J.; Gallego-Perales, J.L.; García-Escobar, E.; Rojo-Martinez, G.; et al. Stearoyl-CoA desaturase-1 is associated with insulin resistance in morbidly obese subjects. Mol. Med. 2011, 17, 273-280. [CrossRef] [PubMed]

25. Rodriguez-Pacheco, F.; Garcia-Serrano, S.; Garcia-Escobar, E.; Gutierrez-Repiso, C.; Garcia-Arnes, J.; Valdes, S.; Gonzalo, M.; Soriguer, F.; Moreno-Ruiz, F.J.; Rodriguez-Cañete, A.; et al. Effects of obesity/fatty acids on the expression of GPR120. Mol. Nutr. Food Res. 2014, 58, 1852-1860. [CrossRef]

26. Rodriguez-Pacheco, F.; Gutierrez-Repiso, C.; Garcia-Serrano, S.; Alaminos-Castillo, M.A.; Ho-Plagaro, A.; Valdes, S.; Garcia-Arnes, J.; Gonzalo, M.; Andrade, R.J.; Moreno-Ruiz, F.J.; et al. The pro-/anti-inflammatory effects of different fatty acids on visceral adipocytes are partially mediated by GPR120. Eur. J. Nutr. 2017, 56, 1743-1752. [CrossRef]

27. Gutierrez-Repiso, C.; Velasco, I.; Garcia-Escobar, E.; Garcia-Serrano, S.; Rodriguez-Pacheco, F.; Linares, F.; de Adana, M.S.R.; Rubio-Martin, E.; Garrido-Sanchez, L.; Cobos-Bravo, J.F.; et al. Does dietary iodine regulate oxidative stress and adiponectin levels in human breast milk? Antioxid. Redox Signal. 2014, 20, 847-853. [CrossRef]

28. Huang, X.; Liu, G.; Guo, J.; Su, Z. The PI3K/AKT pathway in obesity and type 2 diabetes. Int. J. Biol. Sci. 2018, 14, 1483-1496. [CrossRef]

29. Barbarroja, N.; Lopez-Pedrera, R.; Mayas, M.D.; Garcia-Fuentes, E.; Garrido-Sanchez, L.; Macias-Gonzalez, M.; El Bekay, R.; Vidal-Puig, A.; Tinahones, F.J. The obese healthy paradox: Is inflammation the answer? Biochem. J. 2010, 430, 141-149. [CrossRef]

30. Benito, M. Tissue specificity on insulin action and resistance: Past to recent mechanisms. Acta Physiol. 2011, 201, 297-312. [CrossRef]

31. Brozinick, J.T., Jr.; Roberts, B.R.; Dohm, G.L. Defective signaling through Akt-2 and -3 but not Akt-1 in insulin-resistant human skeletal muscle: Potential role in insulin resistance. Diabetes 2003, 52, 935-941. [CrossRef] [PubMed] 
32. Rondinone, C.M.; Wang, L.M.; Lonnroth, P.; Wesslau, C.; Pierce, J.H.; Smith, U. Insulin receptor substrate (IRS) 1 is reduced and IRS-2 is the main docking protein for phosphatidylinositol 3-kinase in adipocytes from subjects with non-insulin-dependent diabetes mellitus. Proc. Natl. Acad. Sci. USA 1997, 94, 4171-4175. [CrossRef] [PubMed]

33. Anai, M.; Funaki, M.; Ogihara, T.; Terasaki, J.; Inukai, K.; Katagiri, H.; Fukushima, Y.; Yazaki, Y.; Kikuchi, M.; Oka, Y.; et al. Altered expression levels and impaired steps in the pathway to phosphatidylinositol 3-kinase activation via insulin receptor substrates 1 and 2 in Zucker fatty rats. Diabetes 1998, 47, 13-23. [CrossRef] [PubMed]

34. Nelson, V.L.; Jiang, Y.P.; Dickman, K.G.; Ballou, L.M.; Lin, R.Z. Adipose tissue insulin resistance due to loss of PI3K p110alpha leads to decreased energy expenditure and obesity. Am. J. Physiol. Endocrinol. Metab. 2014, 306, E1205-E1216. [CrossRef] [PubMed]

35. Gomez-Hernandez, A.; Lopez-Pastor, A.R.; Rubio-Longas, C.; Majewski, P.; Beneit, N.; Viana-Huete, V.; García-Gómez, G.; Fernandez, S.; Hribal, M.L.; Sesti, G.; et al. Specific knockout of p85alpha in brown adipose tissue induces resistance to high-fat diet-induced obesity and its metabolic complications in male mice. Mol. Metab. 2020, 31, 1-13. [CrossRef] [PubMed]

36. Cornier, M.A.; Bessesen, D.H.; Gurevich, I.; Leitner, J.W.; Draznin, B. Nutritional upregulation of p85alpha expression is an early molecular manifestation of insulin resistance. Diabetologia 2006, 49, 748-754. [CrossRef]

37. Ueki, K.; Yballe, C.M.; Brachmann, S.M.; Vicent, D.; Watt, J.M.; Kahn, C.R.; Cantley, L.C. Increased insulin sensitivity in mice lacking p85beta subunit of phosphoinositide 3-kinase. Proc. Natl. Acad. Sci. USA 2002, 99, 419-424. [CrossRef]

38. Miller, M.R.; Pereira, R.I.; Langefeld, C.D.; Lorenzo, C.; Rotter, J.I.; Chen, Y.D.; Bergman, R.N.; Wagenknecht, L.E.; Norris, J.M.; Fingerlin, T.E. Levels of free fatty acids (FFA) are associated with insulin resistance but do not explain the relationship between adiposity and insulin resistance in Hispanic Americans: The IRAS Family Study. J. Clin. Endocrinol. Metab. 2012, 97, 3285-3291. [CrossRef] [PubMed]

39. Piro, S.; Maniscalchi, E.T.; Monello, A.; Pandini, G.; Mascali, L.G.; Rabuazzo, A.M.; Purrello, F. Palmitate affects insulin receptor phosphorylation and intracellular insulin signal in a pancreatic alpha-cell line. Endocrinology 2010, 151, 4197-4206. [CrossRef]

40. Schmitz-Peiffer, C.; Craig, D.L.; Biden, T.J. Ceramide generation is sufficient to account for the inhibition of the insulin-stimulated PKB pathway in C2C12 skeletal muscle cells pretreated with palmitate. J. Biol. Chem. 1999, 274, 24202-24210. [CrossRef]

41. Rehman, K.; Haider, K.; Jabeen, K.; Akash, M.S.H. Current perspectives of oleic acid: Regulation of molecular pathways in mitochondrial and endothelial functioning against insulin resistance and diabetes. Rev. Endocr. Metab. Disord. 2020. [CrossRef] [PubMed]

42. Alkhateeb, H.; Qnais, E. Preventive effect of oleate on palmitate-induced insulin resistance in skeletal muscle and its mechanism of action. J. Physiol. Biochem. 2017, 73, 605-612. [CrossRef] [PubMed]

43. Tardif, N.; Salles, J.; Landrier, J.F.; Mothe-Satney, I.; Guillet, C.; Boue-Vaysse, C.; Combaret, L.; Giraudet, C.; Patrac, V.; Bertrand-Michelh, J. Oleate-enriched diet improves insulin sensitivity and restores muscle protein synthesis in old rats. Clin. Nutr. 2011, 30, 799-806. [CrossRef]

44. Salvado, L.; Coll, T.; Gomez-Foix, A.M.; Salmeron, E.; Barroso, E.; Palomer, X.; Vázquez-Carrera, M. Oleate prevents saturated-fatty-acid-induced ER stress, inflammation and insulin resistance in skeletal muscle cells through an AMPK-dependent mechanism. Diabetologia 2013, 56, 1372-1382. [CrossRef] [PubMed]

45. Fritsche, L.; Weigert, C.; Häring, H.U.; Lehmann, R. How insulin receptor substrate proteins regulate the metabolic capacity of the liver-implications for health and disease. Curr. Med. Chem. 2008, 15, 1316-1329. [CrossRef] [PubMed]

46. Hitomi, H.; Kiyomoto, H.; Nishiyama, A.; Hara, T.; Moriwaki, K.; Kaifu, K.; Ihara, G.; Fujita, Y.; Ugawa, T.; Kohno, M. Aldosterone suppresses insulin signaling via the downregulation of insulin receptor substrate-1 in vascular smooth muscle cells. Hypertension 2007, 50, 750-755. [CrossRef]

47. Akalestou, E.; Genser, L.; Rutter, G.A. Glucocorticoid Metabolism in Obesity and Following Weight Loss. Front. Endocrinol. (Lausanne) 2020, 11, 59. [CrossRef] [PubMed]

48. Folli, F.; Saad, M.J.; Kahn, C.R. Insulin receptor/IRS-1/PI 3-kinase signaling system in corticosteroid-induced insulin resistance. Acta Diabetol. 1996, 33, 185-192. [CrossRef] 
49. Weir, N.L.; Nomura, S.O.; Steffen, B.T.; Guan, W.; Karger, A.B.; Klein, R.; Klein, B.E.K.; Cotch, M.F.; Tsai, M.Y. Associations between omega- 6 polyunsaturated fatty acids, hyperinsulinemia and incident diabetes by race/ethnicity: The Multi-Ethnic Study of Atherosclerosis. Clin. Nutr. 2020. [CrossRef]

50. Lepretti, M.; Martucciello, S.; Burgos Aceves, M.A.; Putti, R.; Lionetti, L. Omega-3 Fatty Acids and Insulin Resistance: Focus on the Regulation of Mitochondria and Endoplasmic Reticulum Stress. Nutrients 2018, 10, 350. [CrossRef] [PubMed]

51. Mauvais-Jarvis, F.; Ueki, K.; Fruman, D.A.; Hirshman, M.F.; Sakamoto, K.; Goodyear, L.J.; Iannacone, M.; Accili, D.; Cantley, L.C.; Kahn, C.R. Reduced expression of the murine p85alpha subunit of phosphoinositide 3-kinase improves insulin signaling and ameliorates diabetes. J. Clin. Investig. 2002, 109, 141-149. [CrossRef] [PubMed]

52. Kovalik, J.P.; Slentz, D.; Stevens, R.D.; Kraus, W.E.; Houmard, J.A.; Nicoll, J.B.; Lea-Currie, Y.R.; Everingham, K.; Kien, C.L.; Buehrer, B.M.; et al. Metabolic remodeling of human skeletal myocytes by cocultured adipocytes depends on the lipolytic state of the system. Diabetes 2011, 60, 1882-1893. [CrossRef] [PubMed]

53. Zhang, M.; Hu, T.; Zhang, S.; Zhou, L. Associations of Different Adipose Tissue Depots with Insulin Resistance: A Systematic Review and Meta-analysis of Observational Studies. Sci. Rep. 2015, 5, 18495. [CrossRef] [PubMed]

54. Cortright, R.N.; Sandhoff, K.M.; Basilio, J.L.; Berggren, J.R.; Hickner, R.C.; Hulver, M.W.; Dohm, G.L.; Houmard, J.A. Skeletal muscle fat oxidation is increased in African-American and white women after 10 days of endurance exercise training. Obesity (Silver Spring) 2006, 14, 1201-1210. [CrossRef]

55. Barakat, H.; Hickner, R.C.; Privette, J.; Bower, J.; Hao, E.; Udupi, V.; Green, A.; Pories, W.; MacDonald, K. Differences in the lipolytic function of adipose tissue preparations from Black American and Caucasian women. Metabolism 2002, 51, 1514-1518. [CrossRef]

(C) 2020 by the authors. Licensee MDPI, Basel, Switzerland. This article is an open access article distributed under the terms and conditions of the Creative Commons Attribution (CC BY) license (http://creativecommons.org/licenses/by/4.0/). 